\title{
THE INFLUENCE OF INK CONCENTRATION AND LAYER THICKNESS ON YELLOW COLOUR REPRODUCTION IN LIQUID ELECTROPHOTOGRAPHY TONER
}

\author{
Igor Majnarić, Aleš Hladnik, Tadeja Muck, Ivana Bolanča Mirković
}

Original scientific paper

In liquid toner electrophotography, colour gamut is often diminished in the yellow region leading to problems with photo quality prints. It is known that the concentration of pigment particles in the printing ink and its thickness when applied on a paper substrate decisively influence final print quality. Variation of these two parameters for the yellow process ink was performed by modifying the printing process of the electrophotographic printer HP Indigo S1000. Printed colour patches of ECI test chart were analysed colorimetrically and using image analysis approach. Two-way analysis of variance was implemented to statistically assess the obtained results. Both studied responses - colour gamut volume and area coverage of halftone dots - were found to be primarily influenced by the yellow ink layer thickness and much less by the ink concentration. Increase from one to two ink layers had a significantly stronger effect on each of the two responses when compared to an additional increase from two to three layers.

Keywords: colour gamut; colour reproduction; halftone dots; liquid toner electrophotography; print quality; tone value

Utjecaj koncentracije bojila i debljine nanosa žute na kolornu reprodukciju s tekućim elektrofotografskim tonerom

Izvorni znanstveni članak

U elektrofotografiji s tekućem tonerom, kolornigamut je često smanjen u žutom području što vodi do problema pri realizaciji otisaka fotografske kvalitete. Poznato je da koncentracija čestica pigmenta u tiskarskom bojilu i debljina nanosa na papirnatoj podlozi utjeću na konačnu kvalitetu otiska. U ovom radu varirana su upravo ta dva parametara, primjenjujući pritom žuto ElectroInk procesno bojilo te elektrofotografski tiskarski stroju HP Indigo. Za kolorimetrijsku i slikovnu analizu primjenjena je ECI tiskovna forma koja sadrži 378 definiranih polja. Dobiveni rezultati statistički su obrađeni metodom dvosmjerne analize varijacija. Studija je prikazana pomoću volumena kolornog gamuta, te površinske pokrivenost rasterskih elemenata (točkica). U radu je utvrđeno je da na kvalitetu obojenja prvenstveno utječe debljina nanosa žutog bojila, dok je utjecaj koncentracije žutih pigmenata minoran. Povećanje nanosa bojila sa jedanog na dva imalo je mnogo jači učinak od onog koji je realiziran povećanjem sa dva sloja na tri sloja.

Ključne riječi: elektrofotografski tekući toner; kolorni gamut; kolorna reprodukcija; kvaliteta otiska; rasterske točke; tonska vrijednost

\section{Introduction}

In obtaining a high-quality colour reproduction, process printing inks (CMYK) and especially their colorants - pigments or dyes - play a decisive role. Ink formulation and the amount of ink being used must meet the requirements of the actual printing technology. In particular, concentration of pigment particles in the yellow ink as well as the final layer thickness of the ink applied to the printing substrate can be varied by a printer to assure the desired reproduction of lighter tones.

The aim of this study was to examine the technological possibilities and limitations related to the use of the yellow process ink within the electrophotographic printing system with the liquid toner - also known as HP ElectroInk. The results should also provide some directions on how to improve the reproduction of yellow colour, obtain higher colour saturation, and consequently, to achieve higher print quality with larger colour gamut.

During the printing process, to attain a larger colour gamut it is common to apply a higher amount of the colorant onto the printing substrate. Technically, this can be accomplished in one of two ways: either by increasing the concentration of the pigmented toner particles in ink or by increasing the number of ink layers.

\section{Liquid electrophotography toner}

The development process in the liquid toner electrophotography is very complicated and consists of several consecutive steps [1]. The final ink layer thickness is primarily influenced by the voltages of the developer drum and the developer rollers. By varying individual voltages, higher colour saturation in prints can be obtained [2].

ElectroInk contains charged pigmented toner particles in a liquid carrier. Similarly to other digital printing technologies, such as dry electrophotography, printing is performed via electrically controlling the location of the toner particles. In its basic state the ink is an emulsion consisting of pigments in a form of a thermal polymer $(24-29 \%)$, which is dispersed in a non-polar volatile oil (70-75\%). The ink also contains additives for increasing the conductivity (about $10 \%$ ) [3]. ElectroInk is supplied as a concentrated paste that is loaded into the press in tubular cartridges. Inside the press it is fed into ink supply tanks and diluted with oil, to form a fluid mixture ready for printing.

During the printing process, the ElectroInk structure rapidly alters. Ink viscosity increases due to a high temperature $\left(\vartheta=125^{\circ} \mathrm{C}\right)$ and loss of the volatile solvent. By heating the thermal polymer, the process of plasticity begins causing the polymer to become suitable for adhering to the printing substrate [4].

Particles of the yellow thermal toner have a characteristic fluffy shape with the size ranging from 1 to $5 \mu \mathrm{m}[5,6]$. Such a shape serves primarily to ease the binding of the conductivity-increasing additives. These polar additives adhere to the pigmented toner particles with their positively charged molecular groups. The particles are then ready to move towards a more positive electrostatic field, i.e. a field with a lower negative charge $[7,8,9]$.

Further ink film thickness increase on the printing substrate is possible by means of an overprinting. Such a 
possibility exists only with satellite electrophotographic machines in which one printing unit is used for printing several inks $[10,11,12,13]$. In this case the printing is done on the already printed (dried) ink layer.

\section{Experimental part}

For the experiment we used ECI test chart (target) with 378 colour patches. The chart was printed with the electrophotographic machine HP Indigo S1000 (resolution: $812 \times 812 \mathrm{dpi}$ ). The printer normally uses four process inks (CMYK) of which the yellow one was modified for the purpose of our study. This (Yellow 74) is an azo-based compound (Dalamar yellow C. I. 11741) with the chemical formula $\mathrm{C}_{18} \mathrm{H}_{18} \mathrm{~N}_{4} \mathrm{O}_{6}$. The printing substrate was a calandered paper with the grammage of $280 \mathrm{~g} / \mathrm{m}^{2}$

By adding various amounts of the pigment, three yellow ink concentrations $(\mathrm{C})$ were prepared $-\mathrm{C} 1=1,28$; $\mathrm{C} 2=1,61$ and $\mathrm{C} 3=1,98$ - characterized by different ink densities as measured by the portable ink density meter EAS-1120-53 that was developed by HP Indigo. In addition, the repetition of individual yellow colour separations was accomplished. In this way YMCK (with one yellow layer; L1), YYMCK (with two yellow layers; L2) and YYYMCK prints (with three yellow layers; L3) were made. Consequently, nine different combinations of yellow ink concentration-ink layer thickness were investigated as schematically displayed in Fig. 1.

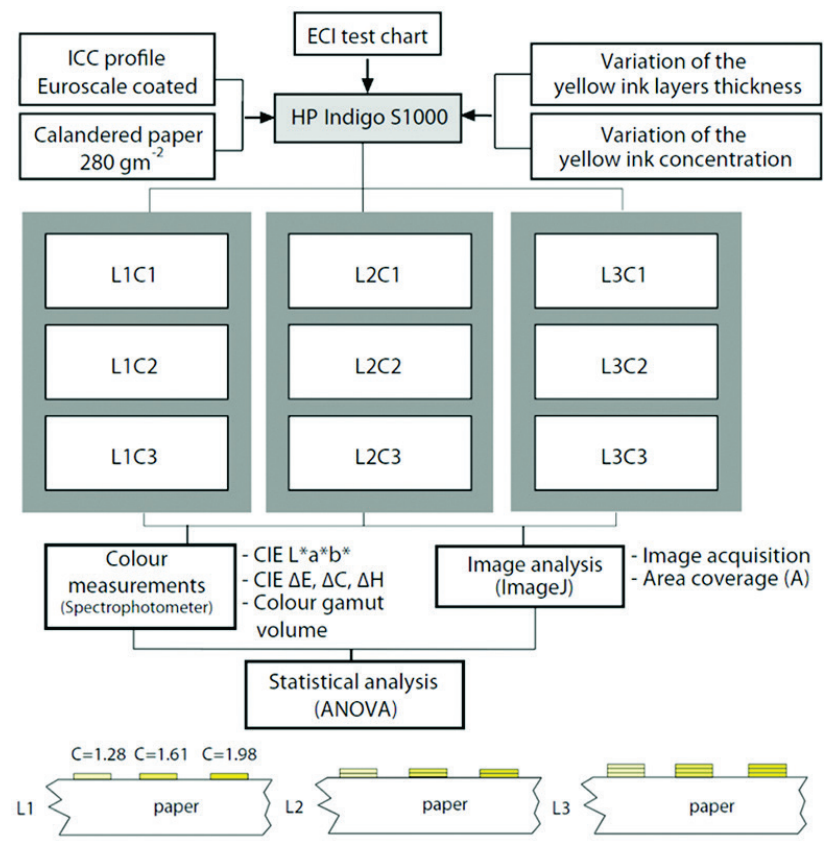

Figure 1 Left: Design of experiments; three yellow ink concentrations (C1, C2, C3) combined with different numbers of yellow ink layers (L1, L2, L3). Top: Total workflow of the study.

Printed colour patches were examined by spectrophotometer X-rite DTP 20 using $0 / 45^{\circ}$ measuring geometry. The obtained $\mathrm{L}^{*} \mathrm{a} * \mathrm{~b} *$ values were used for the calculation of colour differences (CIE LAB delta E2000) and colour gamut volumes (Monaco Profiler Platinum Version). Digital images of the printed halftone dots were obtained by Leica DR 2400 optical microscope with a built-in 1,3 megapixels Dinolite camera. Subsequent image analysis was performed by means of ImageJ software $[14,15,16]$. All major processing steps of our study are presented in Fig. 1.

\section{Results and discussion}

Colorimetric data for the 378 printed colour patches enabled calculations of colour gamut volumes for each of the nine ink concentration - ink layer thickness combinations. CIE $a^{*} b^{*}$ diagrams for the three typical lightness $\left(\mathrm{L}^{*}\right)$ values are displayed in Figs. 2 and 3.
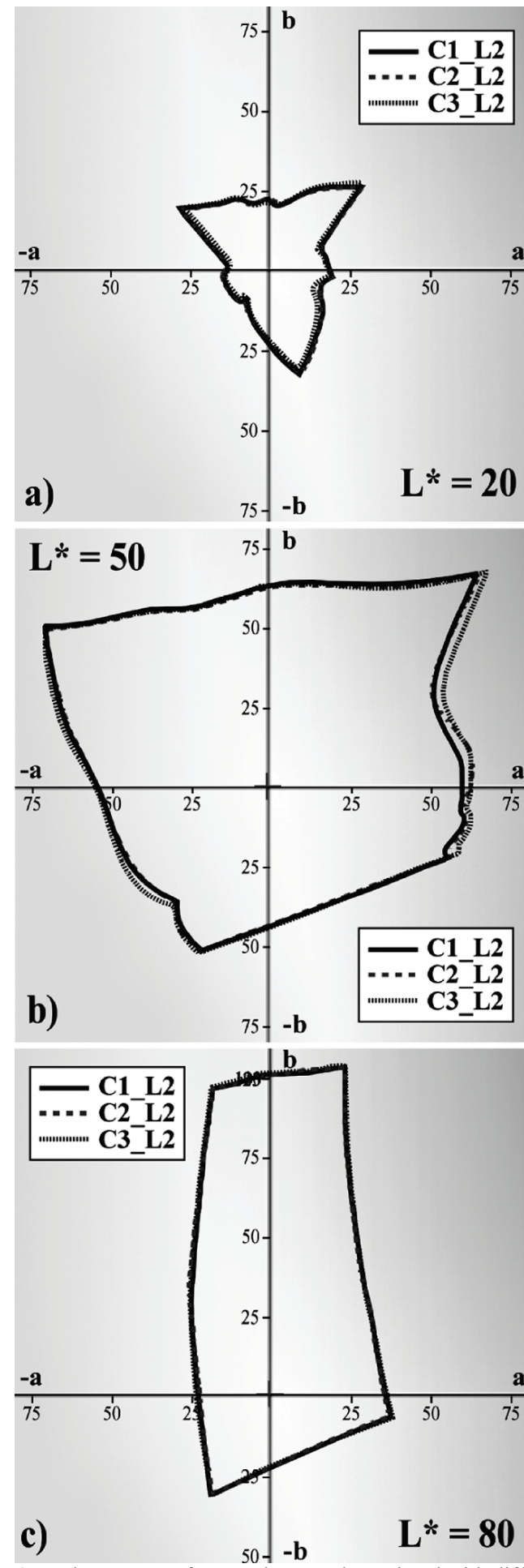

Figure 2 2D colour gamuts for test chart patches printed with different concentrations and constant number of layers (= two; L2) shown for $\mathrm{L}^{*}=20$ (top), $\mathrm{L}^{*}=50$ (middle) and $\mathrm{L}^{*}=80$ (bottom) 

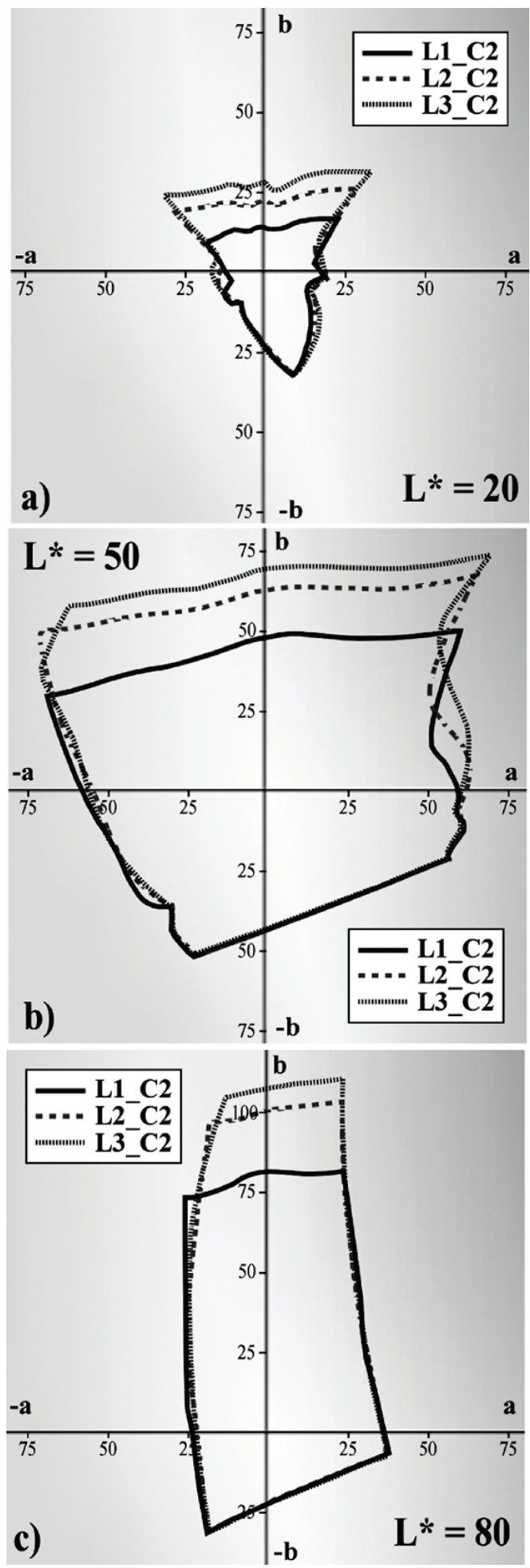

Figure $32 \mathrm{D}$ colour gamuts for test chart patches printed with different numbers of layers and constant ink concentration $(=\mathrm{C} 2)$ shown for $\mathrm{L}^{*}=20$ (top), $\mathrm{L}^{*}=50$ (middle) and $\mathrm{L}^{*}=80$ (bottom).

During printing, the simplest control parameter for halftone value transfer is the measurement of the dot percentage in the halftone patches of the ECI test chart. Variation of the two investigated parameters - yellow ink concentration and ink layer thickness - directly affected the appearance and characteristics of the halftone dots and, consequently, caused the tone value increase (dot gain). Yellow halftone patches at $50 \% \mathrm{~A}$ (tone value) were subsequently analysed. Fig. 4 shows six typical halftone yellow patches at $50 \% \mathrm{~A}$.

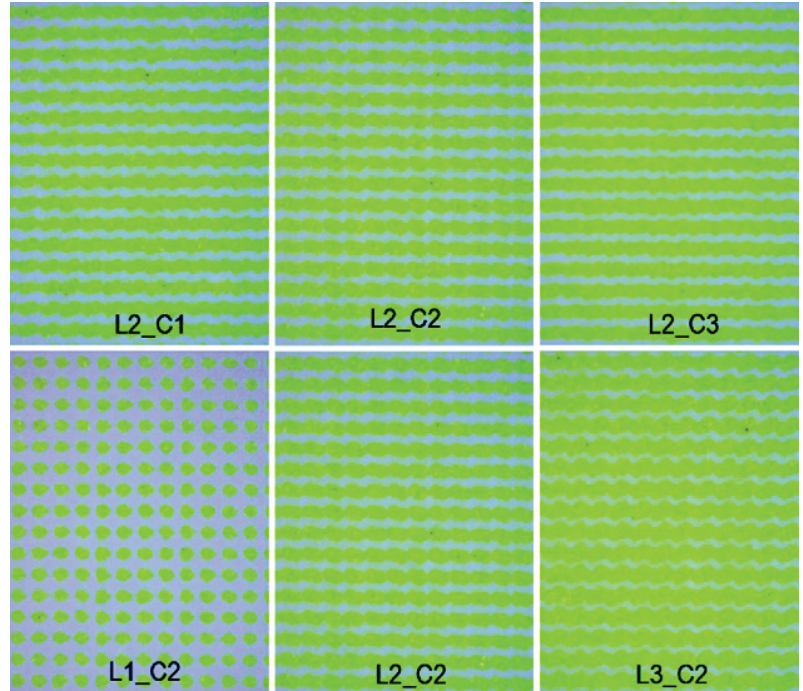

Figure 4 Yellow halftone patches at $50 \%$ A (magnification: $60 \times$ ).

Yellow halftone patches at $50 \% \mathrm{~A}$ were further processed using image analysis approach. Each imaged printed patch was converted into a grayscale - and finally into a binary image using intensity thresholding (Otsu's method). Tone value - percentage of area covered by halftone dots - was calculated.

Two-way analysis of variance (ANOVA) results for colour gamut volume and area coverage at the $95 \%$ confidence level are displayed in Tab. 1 and Tab. 2, respectively. Since five measurements were obtained for each of the nine ink concentration - layer thickness combinations, it was also possible to estimate the interaction effect between the two investigated parameters.
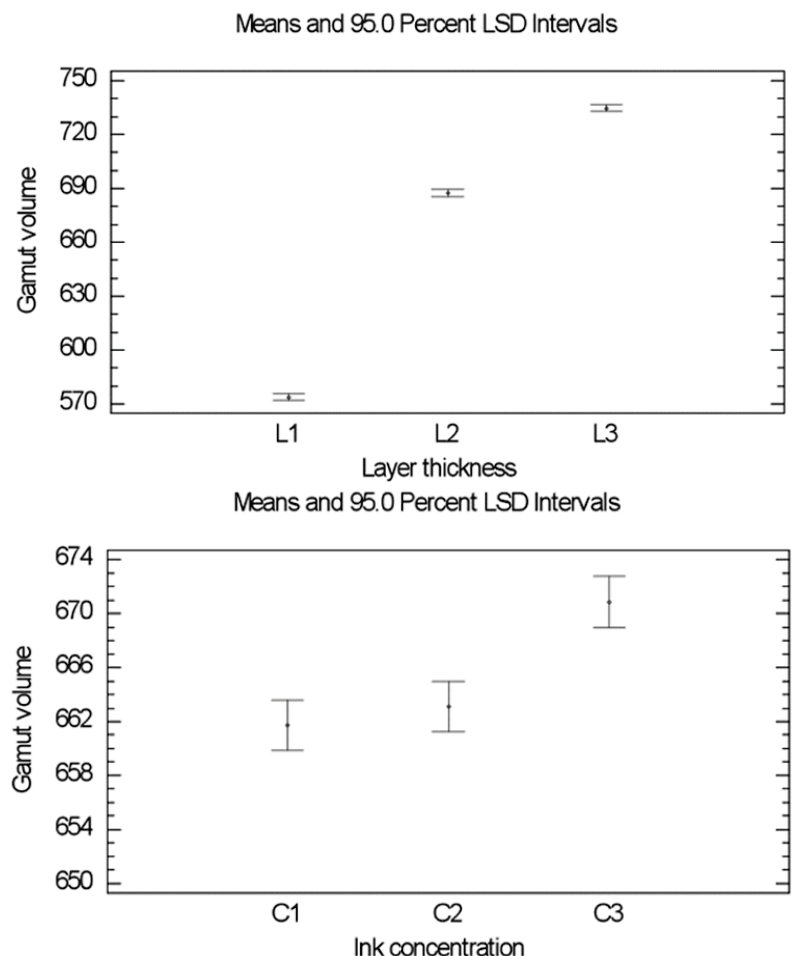

Figure 5 Effects of ink layer thickness (left) and ink concentration (right) on colour gamut volume of ECI test chart patches. 
Table 1 ANOVA table for colour gamut volume

\begin{tabular}{|c|c|c|c|c|c|}
\hline Source & Sum of Squares & Df & Mean Square & F-Ratio & P-Value \\
\hline MAIN EFFECTS & & & & & \\
\hline A: Layer thickness & 205542 & 2 & 102771 & 4033,26 & 0,0000 \\
\hline B: Ink concentration & 729,136 & 2 & 364,568 & 14,31 & 0,0000 \\
\hline INTERACTIONS & & & & & \\
\hline AB & 275,306 & 4 & 68,8265 & 2,70 & 0,0458 \\
\hline RESIDUAL & 917,311 & 36 & 25,4809 & & \\
\hline TOTAL (CORRECTED) & 207464 & 44 & & & \\
\hline
\end{tabular}

Table 2 ANOVA table for area coverage

Table 2 ANOVA table for area coverage
\begin{tabular}{|c|c|c|c|c|c|}
\hline Source & Sum of Squares & Df & Mean Square & F-Ratio & P-Value \\
\hline MAIN EFFECTS & & & & & \\
\hline A:Layer thickness & 1633,94 & 2 & 816,971 & 20,97 & 0,0000 \\
\hline B:Ink concentration & 66,7897 & 2 & 33,3949 & 0,86 & 0,4328 \\
\hline INTERACTIONS & & & & & \\
\hline AB & 84,7066 & 4 & 21,1766 & 0,54 & 0,7047 \\
\hline RESIDUAL & 1402,28 & 36 & 38,9523 & & \\
\hline TOTAL (CORRECTED) & 3187,72 & 44 & & & \\
\hline
\end{tabular}

Means and 95.0 Percent LSD Intervals

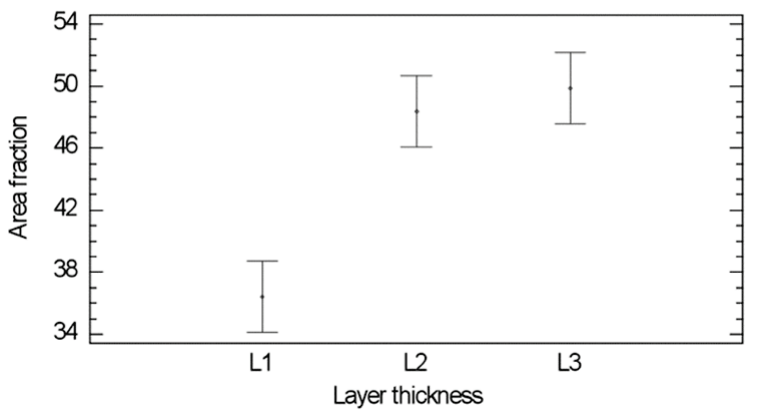

Means and 95.0 Percent LSD Intervals

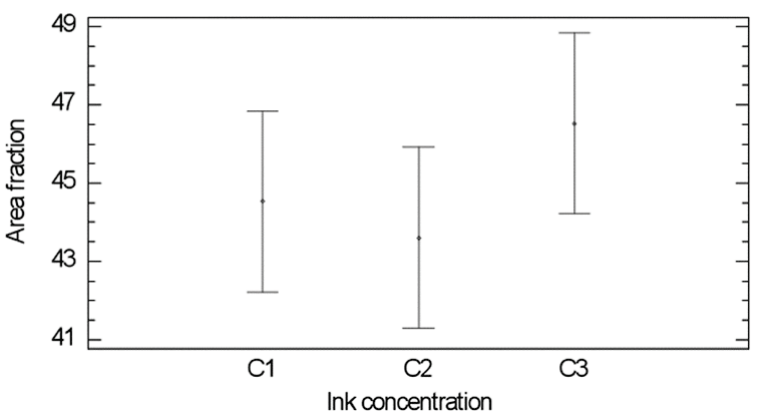

Figure 6 Effects of ink layer thickness (left) and ink concentration (right) on area coverage in yellow halftone patches.

ANOVA results show that both layer thickness and ink concentration have statistically significant effects on color gamut volume at $95 \%$ confidence level. Increasing the values of each of the two parameters results in a larger gamut volume (Fig. 5). Significance of the interaction effect $(P$-value $<0,05)$ is almost exclusively due to the extremely large contribution of the first factor - layer thickness. On the other hand, tone value increase (dot gain) is only influenced by the number of yellow ink layers, i.e. layer thickness, while ink concentration has virtually no impact on this dependent variable (Tab. 2 and Fig. 6). It can be noticed that an increase in the number of ink layers from 1 to 2 has a much stronger effect on both dependent variables when compared to the further addition of the third layer (L2 $\rightarrow$ L3).

\section{Conclusions}

Our study suggests that a higher colour gamut volume in yellow colour region can be achieved primarily by multilayer printing, i.e. by increasing the number of yellow ink layers - especially from one to two - and much less by raising the concentration of the pigmented toner particles in the yellow ink. Such an increase in layer thickness, however, has a detrimental effect on the characteristics of the printed halftone dots, causing an undesirable tone value increase (dot gain). Multilayer printing increases the dynamic range but at the same time reduces bit depth of a printed image. Therefore, if we want to increase the colour gamut volume and preserve optimal dynamic range, it is recommended to use two layers printing only for reproducing solid yellow tones.

\section{Acknowledgements}

This work was supported by the Ministry of Science, Education and Sports of the Republic of Croatia (New formulations of materials, features prints - code: 1281281955-1953 and Study on technological factors of graphic design and the systematic improvement of quality - code: 128-1281955-1962).

\section{References}

[1] Chatow, C.; Udi, C. The Fundamentals of Indigo's Digital Offset Colour Printing Process and How it Rivals Mechanical Offset Printing. // NIP18 Proceedings of International Conference on Digital Printing Technologies / San Diego, California, 2002, pp. 125-128.

[2] Majnaric, I.; Bolanča, Z.; Bolanča Mirković, I. The Influence of the Developer Drum Voltage on Screen Dot Formation.// Proceedings of $20^{\text {th }}$ International DAAAM Symposium "Intelligent Manufacturing \& Automation Focus on Theory, Practice and Education". / Vienna, Austria, 2009, pp. 607-608.

[3] Goldmann, G.; The World of Printers. Oce Printing Systems GmbH, Dusseldorf, Germany, 2004.

[4] Majnaric, I.; Bolanča, I.; Bolanča, Z.; Milković, M. Condition in Digital Printing of Packaging on the Print Quality. // Proceedings of International Conference on Digital Production Printing and Industrial Applications. / Amsterdam, Niderland, 2005, pp. 97-99. 
[5] HP ElectroInk Frequently Asked Questions. 2013. URL: http://www.thedigitalprinters.com/faq/assets/Electroink\%20 FAQ.pdf. (5. 4. 2013.)

[6] Aqua, T.; Salalha, W.; Reznik, S.; Zussman E. Experimental and Analytical Study of Dot Gain Between Elastic and Deformable Drums. // NIP29 Proceedings of the 29th International Conference on Digital Printing Technologies and Digital Fabrication / Seattle, Washington, 2013, pp. 72-74.

[7] Kahatabi, R.; Salalha, W.Forgacs, P.; Yacoub, N.; Avramov, D. Israel, H. I. Dielectric Properties Study of Thin Polymer Film Layers. // NIP28 Proceedings of the 28th International Conference on Digital Printing Technologies and Digital Fabrication / Quebec City, Canada, 2012, pp. 287-290.

[8] Forgacs, P.; Teishev, A. Electro-Rheological Model of HPIndigo ElectroInk. // NIP28 Proceedings of the $28^{\text {th }}$ International Conference on Digital Printing Technologies and Digital Fabrication / Quebec City, Canada, 2012, pp. 348-351.

[9] Forgacs, P. Theory of Ink Transfer in HP-Indigo Digital Press Machines. // NIP29 Proceedings of the $29^{\text {th }}$ International Conference on Digital Printing Technologies and Digital Fabrication/ Seattle, Washington, 2013. pp. 429-432.

[10] Rong, X.; Obispo, S. L. Quality Comparison of HP Indigo to Offset Lithography. // NIP25 Proceedings of $25^{\text {th }}$ International Conference on Digital Printing Technologies and Digital Fabrication / Louisville, Kentucky, 2012, pp. 478-481.

[11] Ruizhi, S.; Bing, S.; Xiao, Z.; Qiang, S. Tone Reproduction Characteristic of Digital Printing.// NIP28 Proceedings of the $28^{\text {th }}$ International Conference on Digital Printing Technologies and Digital Fabrication / Quebec City, Canada, 2012, pp. 242-245.

[12] Tagansky, B. HP-Indigo Technology and its Application to Photo Printing. // NIP28 Proceedings of the $28^{\text {th }}$ International Conference on Digital Printing Technologies and Digital Fabrication / Quebec City, Canada, 2012, pp. 31-34.

[13] Možina, K.; Medved, T.; Rat, B.; Bračko, S. Influence of Light on Typographic and Colorimetric Properties of Ink Jet Prints. // Journal of Imaging Science and Technology. 54, 6(2010), pp. 060403-060403-8.

[14] Rasband, W. S. ImageJ, U. S. National Institutes of Health, Bethesda, Maryland, USA. 1997-2013. URL: http://imagej.nih.gov/ij/(16. 4. 2013.)

[15] Dzik, P.; Furst, T.; Vesely, M.; Kacerova, S.;Stepankova, E.; Smejkalova, H. Image Permanence Evaluation by Color Gamut Volume Change. // Journal of Imaging Science and Technology. 56, 6(2012), pp. 060506-1- 060506-9.

[16] Grilj, S.; Muck T.; Gregor Svetec, D. The ageing resistance of offset and electrophotographic prints. // Nordic Pulp and Paper Research Journal. 27, 4(2012), pp. 739-749.

\section{Authors' addresses}

Assist. Prof. dr. sc. Igor Majnarić

University of Zagreb, Faculty of Graphic Arts, Getaldićeva 2, 10000 Zagreb, Croatia E-mail: majnaric@grf.hr

Prof. dr. sc. Aleš Hladnik

University of Ljubljana, Faculty of Natural Sciences and Engineering, Department of Textiles, Snežniška 5, 1000 Ljubljana, Slovenia E-mail: ales.hladnik@ntf.uni-lj.si

Prof. dr. sc. Tadeja Muck

University of Ljubljana, Faculty of Natural Sciences and Engineering, Department of Textiles, Snežniška 5, 1000 Ljubljana, Slovenia E-mail: tadeja.muck@gmail.com

Assist. Prof. dr. sc. Ivana Bolanča Mirković University of Zagreb, Faculty of Graphic Arts, Getaldićeva 2, 10000 Zagreb, Croatia E-mail: ibolanca@grf.hr 